\title{
The problem of mounting income inequalities in the world vis-a-vis the phenomenon of harmful tax competition. The ICIJ tracking down the greatest financial scandals of the $21^{\text {st }}$ century
}

\begin{abstract}
In May 2016, over 350 economists from thirty states signed a letter to global political leaders and the G-7 in particular, warning that tax havens are socially unfair and have no economic justification whatsoever. The author of the best selling Capital in the Twenty-First Century, Thomas Piketty, Professor of Columbia University, the adviser to the UN Secretary General Jeffrey Sachs and Professor of Princeton University and Nobel Winner, Angus Deaton, alongside many renowned academics, called to make the global tax system more transparent and to introduce regulations that would curb the activities of Offshore Financial Centers (OFCs). An NGO Oxfam International, which coordinated the writing of the letter, called upon global leaders to develop a joint standpoint to abandon the secrecy of business operations in tax havens and reveal what harms they bring. According to the analysts from Oxfam, Credit Suisse and UNCTAD, what is called tax optimization actually contributes to greater global income disparities, which are treated as the gravest global issue in the $21^{\text {st }}$ century. The author refers to academic analyses and the results of the journalistic investigations of the International Consortium of Investigative Journalists (ICIJ) in an attempt to diagnose and examine those mutual dependencies and to present the various harms the procedure brings to economies and societies, and presents his own assessment and forecasts for the future.
\end{abstract}

Key words: harmful tax competition, global economy, income disparities, tax havens

\section{Introduction}

A ccording to a well-known non-governmental organization Oxfam, the size of the global economy has more than doubled over the past thirty years. In 2014, its value reached nearly USD 78 trillion. As production and output continue to grow, there have been absolute increases in gross domestic product (GDP) - one of the main indicators of economic prosperity - in every region of the world over this period. In South Asia, combined GDP in 2014 was more than five times what it was in 1985. Over the past thirty years, average annual GDP growth has been higher in low- and middle-income countries than in richer ones. Between 1990 and 2011 economic growth in the Asian region helped nearly a billion people to escape extreme poverty. The proportion of the world's population living in extreme poverty fell from $36 \%$ in 1990 to $16 \%$ in 2010 . The global economy - Oxfam demonstrates - has been growing, but as incomes and wealth have become detached from productivity and real added value, the people who work hard, but who are not in positions of economic and political power, have lost out. The share of income going to labor compared with capital is in decline, the gap between wages and productivity is growing and income inequality is slowing overall growth, further hurting the poorest people most and preventing millions of people from escaping poverty. In effect, the gap between the rich and poor is reaching new extremes (An economy for, 2016). 


\section{The problem of global income disparities as analyzed by Credit Suisse and Oxfam International}

The Global Wealth Report 2015, prepared by Credit Suisse, estimates that the top percentile of the global population own half of all household assets in the world. It shows that for a number of reasons, wealth varies greatly across individuals. Their estimates suggest that the lower half of the global population collectively own less than $1 \%$ of global wealth, while the richest $10 \%$ of adults own $88 \%$ of all wealth, and the top $1 \%$ account for half of all assets in the world. The trend in recent years has been towards increasing inequality, propelled in part by the rising share of financial assets, which are disproportionately held by the more wealthy individuals. Credit Suisse estimates that 3.4 billion individuals $-71 \%$ of all adults in the world - had wealth below USD 10,000 in 2015 . A further billion adults ( $21 \%$ of the global population) fall in the USD $10,000-100,000$ range. While average wealth is modest in the base and middle tiers of the pyramid, total wealth here amounts to USD 39 trillion, underlining the economic importance of this often neglected segment. Each of the remaining 383 million adults ( $8 \%$ of the world) has net worth above USD 100,000. This group includes 34 million US dollar millionaires, who comprise less than $1 \%$ of the world's adult population, yet own $45 \%$ of all household wealth. 123,800 individuals within this group are worth more than USD 50 million, and 44,900 have over USD 100 million (Credit Suisse, 2015).

Figure 1. The global wealth pyramid

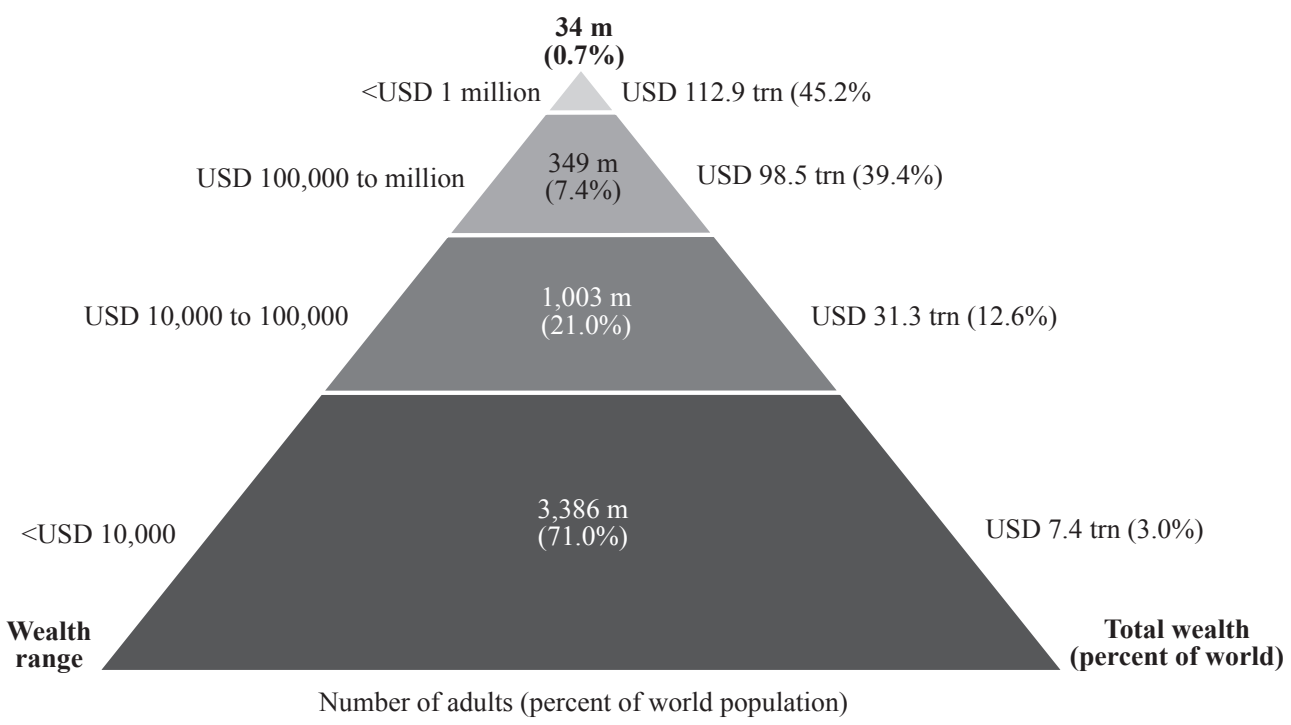

Source: Global Wealth Report 2015, Global Research Institute, Thought leadership from Credit Suisse Research and the world's foremost experts, October 2015.

Also, the newest Oxfam report An Economy for the 1\%, shows that the wealth of the poorest half of the world's population has fallen by a trillion dollars since 2010, a drop of $38 \%$. This has occurred despite the global population increasing by around 400 mil- 
lion people during that period. Meanwhile, the wealth of the richest 62 individuals has increased by more than half a trillion dollars to USD 1.76 trillion. The report also shows how women are disproportionately affected by inequality - of the current ' 62 ', 53 are men and only nine are women. Although the number of people living in extreme poverty halved between 1990 and 2010, the average annual income of the poorest $10 \%$ has risen by less than USD 3 a year in the past quarter of a century. That equates to an increase in individuals' daily income of less than a single cent a year ( 62 people own, 2016). "There is no getting away from the fact that the big winners in our global economy are those at the top. Our economic system is heavily skewed in their favour, and arguably increasingly so. Far from trickling down, income and wealth are instead being sucked upwards at an alarming rate. Once there, an ever more elaborate system of tax havens and an industry of wealth managers ensure that it stays there, far from the reach of ordinary citizens and their governments. One recent estimate is that USD 7.6 trillion of individual wealth - more than the combined gross domestic product (GDP) of the UK and Germany - is currently held offshore" - we can read in the report conclusions (Ibid.).

Oxfam is calling for action against tax havens to be part of a three-pronged attack on inequality. Action to recover the missing billions lost to tax havens needs to be accompanied by a commitment on the part of governments to invest in healthcare, schools and other vital public services that make such a big difference to the lives of the poorest people (Ibid.). What is needed, declares Oxfam, is a multi-pronged strategy to rebalance power within global and national economies, empowering people who are currently excluded and keeping the influence of the rich and powerful in check. This is necessary for economies to work better in the interests of the majority, and in particular in the interests of the poorest people, who have the most to gain from a fairer distribution of income and wealth. To achieve this, Oxfam makes many recommendations. One of them is to share the tax burden fairly to level the playing field, because too much wealth is concentrated in the hands of the few. The tax burden is falling on ordinary people, while the richest companies and individuals pay too little. Governments must act together to correct this imbalance. Specific commitments must include: shifting the tax burden away from labor and consumption and towards wealth, capital and income from these assets; transparency of tax incentives; and national wealth taxes. As a priority, Oxfam is calling on world leaders to agree a global approach to end the era of tax havens (62 people own, 2016).

Oxfam is calling for urgent action to tackle the extreme inequality crisis which threatens to undermine the progress made in tackling poverty during the last quarter of a century. As a priority, it is calling for an end to the era of tax havens which has seen the increasing use of offshore centers by rich individuals and companies to avoid paying their fair share to society. This has denied governments valuable resources needed to tackle poverty and inequality (Ibid.; We've already solved, 2016; Oxfam says wealth, 2016).

\section{The notion and significance of international financial service centers called tax havens}

What does the global phenomenon of tax havens consist in, then? What are the benefits and threats of their operations? Should their activities be better monitored and more 
transparent, and if so - why is that? Do the analyses of Credit Suisse and Oxfam International present the truth about the primary reason for the harmful income inequality around the world?

Tax havens are commonly recognized as "states or territories that ensure tax benefits to natural or legal persons, with respect to income tax or inheritance tax, in the sense that they admit relatively lower taxes and allow taxpayers to avoid tax burdens of their home countries" (Kuciak, 2012, pp. 48-88; Mazur, 2012, pp. 15-19; What does offshore). A tax haven can also be defined as a "state where the legal system, regulations, traditions and, in some cases, also provisions enshrined in international agreements allow individuals to slash the total fiscal burden" (Grzywacz, 2011, pp. 58-108).

The issue of globally operating offshore financial centers (OFC) has long been tackled by the OECD, albeit ineffectively (OECD, 2010). The OECD has developed also a catalogue of criteria allowing a given tax system to be deemed a tax haven, including the following:

- zero or very low taxes;

- unequal approach to taxes on income generated by the assets located in a given state and to income 'transferred' to this state which is taxed at preferential rates;

- the absence of the requirement that tax regulations be transparent thereby allowing certain entities to enjoy special tax privileges;

- the absence of efficient information exchange (high secrecy) - reluctance of a given state's administration to partake in the exchange of tax information (and waive regulations on bank secrets) understood as refusing to impart information to administrations of other states on income transferred by non-residents;

- the absence of the requirement to run activities in the tax haven concerned (Kuciak, 2012, pp. 48-88).

Other classifications point to the following features of offshore legislative systems: no or nominal tax on the relevant income; lack of effective exchange of information with other states; lack of transparency; lack of commitment to implement effective information exchange on tax with other states; liberal regulations pertaining to business activities and registration of companies; economic and political stability; advanced banking, transportation and telecommunications infrastructure; convenient location; extensive network of consulting, legal and accounting companies; legal guarantees against expropriation or nationalization; the possibility to purchase real estate; low fees; quick handling of formalities (Langer, 2007; Lipowski, 2002).

The majority of tax havens are typically located on small, beautiful and exotic islands and in small states with a colonial past with no natural resources; sometimes their development is based on small-scale fishing, but mostly it relies on an extensive sector of financial and tourist services. According to estimates by the IMF, they serve as domiciles to approximately 4,000 banks, 2,000,000 companies and nearly seventy investment and retirement funds of all kinds, frequently speculative (hedge funds). The biggest world banks, such as Citigroup, Morgan Stanley and Bank of America, BNP - Paribas, Societe Generale and Telecom (Winter, 2010, pp. 19-59), have a number of their branches in tax haves. Recently, there have been around fifty active tax havens in the world, mostly clustered in the Caribbean, parts of the United States (Delaware and Nevada), South-East Europe, Asia, and in the Indian and Pacific Oceans. The amount 
of financial resources held in these types of jurisdictions is unknowable. Boston Consulting Group experts reckon that out of the total of USD 123 trillion of private assets, approximately USD 8 trillion sits offshore. These statistics do not include real estate, yachts and other fixed assets. The OECD assesses these amounts within the USD 5-7 trillion range, while the US Department of State Bureau for International Narcotics and Law Enforcement Affairs estimates that USD 4.8 trillion is held in tax havens. James Henry, a former chief economist of the renowned consulting network McKinsey \& Company, and advisor to the non-governmental organization Tax Justice Network, in the report The Price of Offshore Revisited, presents calculations that the tax-free amounts held in offshore centers (unreported private financial wealth) reach the level of as much as USD 21 trillion, that is the equivalent of the combined GDP of the US and Japan. These estimates are typically deemed to be exaggerated, however (Special Report, 2013; Wojtasik, 2016). ${ }^{1}$

Tax havens are true 'global giants' in some sectors. The Cayman Islands (population: 57,000) are the world's leader of hedge funds. There are nearly 18,000 companies (Virtual Offices) registered in one, albeit highly famous, office building Ugland House in George Town, in the Cayman Islands (Ugland House). Bermuda (population: 65,000) is number one in reinsurance services. L. Winter reports that at the beginning of the 1990s bank deposits held in Jersey went up by nearly $20 \%$ over just two years. Bermuda has become "the richest country in the world" with GDP per capita of nearly USD 70,000. The Cayman Islands have registered around 1,000 new companies every year and around 60,000 companies are registered in the British Virgin Islands annually. Although Switzerland continues to be the leader in managing private assets (USD 2.1 trillion in 2013) it has to stand up to Asian private banking centers, especially Singapore and Hong Kong, which are becoming increasingly attractive to different entities from India, China and Indonesia in terms of the number of deposits held.

The heavily publicized cases of US corporations, such as Google, Apple, Amazon and Starbucks, which failed to pay billions of dollars to the federal budget, are only the tip of the iceberg. Nearly one hundred of the biggest corporations in the US alone have created offshore companies in tax havens to avoid due taxes, which is highly criticized by average US citizens suffering in the aftermath of the 2008 financial crisis.

\footnotetext{
1 There are a number of different mechanisms to carry out financial operations in tax havens. The most frequent one is the corporate vehicle, which involves two (or more) companies linked by their shares. The process starts with establishing a mother company in a tax haven. This company then sets up another company - a daughter company, seated in a place that is not listed as a tax haven, but has a friendly tax policy (such as the state of Delaware in the US). On account of this structure of shares, the role of the operating company (that is the one that signs contracts, has a bank account, makes out invoices, receives payments, carries out contract work and so on) is played by the daughter company, registered in a location that is not blacklisted as a place with a harmful tax policy. Consequently, the profits of the operating company are directly received by its shareholder (the mother company located in a tax haven) which enjoys the privileges of tax havens. Companies located in other countries with advantageous tax systems can also serve the purpose of artificial generating high expenses attributed to the operations of mother companies. A company located in a tax haven can deliberately be paid excessive rates for leasing a trademark, providing know-how or advisory services, for instance. Consequently, the daughter company has much higher deductible expenses, generates considerably lower or no income thus paying a lower or no tax in the home country.
} 
The Obama administration has greatly stimulated global activities seeking to increase the transparency and monitoring of the global system of financial operations, in particular in 2010, when the US Congress passed the Foreign Account Tax Compliance Act (FATCA). It requires foreign financial institutions, such as banks operating in tax havens, to identify account owners and investors who can potentially be US citizens and provide the Internal Revenue Service (IRS) with information about their financial accounts. If their clients refuse to answer enquiries from IRS officials, they pay a $30 \%$ tax on income generated in the US. FATCA also aims to prevent US citizens and green card holders from concealing their income outside the US. Individuals possessing assets of over USD 50,000 held in foreign banks are required to report them on a special form attached to a standard tax return statement. FATCA entered into force in 2014, after a four-year delay, and it is difficult to assess its practical outcomes. It is to be gradually implemented over the period of four years, completed in 2018. Some experts believe that it may contribute to the creation of a desirable "global financial register" including all the information about the owners of assets deposited in all banks. Influential US media suggested that Congress introduce legal regulations necessary in order to yank money back from tax havens in order to alleviate social tensions mounting due to income inequalities. The enforcement of tax regulations and corporate regulations as well as transparency in this respect is a top priority also for the United Kingdom. Public debate on the sanctions imposed on entities taking advantage of tax havens has also intensified in France, leading to concrete legal regulations (Special Report: offshore, 2013; The Price of Offshore, 2012).

\section{Offshore Leaks, Lux Leaks and Swiss Leaks, or economic and social threats related to international tax optimization}

Different studies evidence that around half of global capital flow is effected through tax havens. According to Merrill Lynch in Capgemini's World Wealth Report, the value of assets held in tax haves goes up by USD 600 billion annually. A considerable proportion of financial assets in tax havens comes from money laundering. The IMF points to as much as $2-5 \%$ of global GDP lost on account of these practices. According to estimates by the Financial Action Task Force (FATF), the value of income generated by illicit activity amounts to USD 3 trillion. In practice, every more or less sophisticated money laundering method needs an offshore company to be registered. Another increasingly popular method involves anonymous laundering on the Internet, named cyberlaundering (using the system of e-cash and digital cash; smart cards; data encrypting systems: one-way-privacy; money-mules; and Internet casinos) (Grzywacz, 2011, pp. 58-108). A special and highly interesting report by The Economist says that even most conservative estimates show that the outflow of assets linked to money laundering, corruption, frauds, tax avoidance and deliberately or accidentally mispriced commercial transactions exceed total inflows of global aid to low and middle income states. A group of 139 such (low-middle-income) economies is estimated to have lost up to USD 9.3 trillion on account of unregistered economic activity on their territories. "Developing countries as a whole don't face a debt problem, but a huge offshore tax-evasion and money-launder- 
ing problem," concludes the magazine (Special Report: offshore, 2013). Critics of such financial mechanisms emphasize that tax optimization brings obvious losses to budget incomes of the states whose capital flows out, further increasing the imbalance in public finances. This, in turn, makes it necessary to increase the tax burdens of those domestic business entities (natural and legal persons) who do not want to, or cannot shuffle their money. The consequence is that the increasingly fiscal policy hobbles economic development and skews the desirable direction of socio-economic development of the country. An increasing proportion of society perceives tax optimization to be dishonest towards a definite majority of fair taxpayers who are periodically checked by tax authorities. The Tax Justice Network publishes the annual Financial Secrecy Index for tax havens. Other economies, including the US and EU, lose tax revenues at a minimum amount of USD 255 billion annually to tax havens. Offshore financial centers facilitate also money laundering, organized crime and international terrorism. ${ }^{2}$

The investigation carried out by the International Consortium of Investigative Journalists (ICIJ), an organization playing a critical role in efficiently solving the problem, revealed that as many as 130,000 individuals from 170 countries hold assets in the British Virgin Islands, the second most popular location after the Cayman Islands. The ICIJ got hold of discs with a total of 260 gigabytes of data (including 2 million emails and other documents) on thousands of secret accounts. These details were subsequently made available to 38 media outlets from 46 countries. The British and US editions of The Guardian started their publication. In 2013, Gerard Ryle from ICIJ disclosed a disc with dozens gigabytes of confidential data, obtained from two offshore middlemen, to several dozen journalists involved in the project and working for the most influential global media. An international team of journalists examined them and discovered that secret accounts or companies in tax havens were opened not only by businessmen, but also by famous politicians and their families, sportspeople, artists, celebrities and even ordinary representatives of the middle class - doctors, farmers, officials, military officers and so on. In order to avoid progressive taxes in their home economies, these people decided to shuffle their incomes to tax havens, seeking savings generated by considerably lower,

2015 Secrecy Ranking:

1. Switzerland,

2. Hong Kong,

3. USA,

4. Singapore,

5. Cayman Islands*,

6. Luxembourg,

7. Lebanon,

8. Germany,

9. Bahrain,

10. United Arab Emirates (Dubai),

11. Macao,

12. Japan,

13. Panama,

14. Marshall Islands,

15. United Kingdom*.

* British overseas territory or crown dependency. If Britain's network were assessed together, it would be at the top. Source: http://www.financialsecrecyindex.com/. See also: Henry, 2012. 
or even zero tax rates. The ICIJ posted the database with the details of companies and foundations with accounts in tax havens on the Internet. The list, posted on the official website of the ICIJ: https://offshoreleaks.icij.org/, features around 100,000 companies from all over the world and an enormous database, Offshore Leaks Database, with details of companies, business groups, foundations and private individuals who used to have or still have secret accounts in tax havens. The search can be carried out easily by business addresses, their names or the names of the owners. According to the ICIJ, the database contains details of different companies registered in tax havens over the last thirty years. ${ }^{3}$

The information imparted by the ICIJ and corroborated by the analyses of the Tax Justice Network intensified the debate on profits and losses generated by international tax optimization on the one hand, and on the other it accelerated the activities of many countries seeking to curb the possibilities to take advantage of privileges offered by OFCs. ${ }^{4}$ After the US adopted the Foreign Account Tax Compliance Act (FATCA), a component of the Hiring Incentives to Restore Employment (HIRE) Act in 2013, France and the United Kingdom declared their intention to intensify combat against tax havens. The ICIJ report, which is based on an investigation carried out by the most experienced investigative journalists from German Süddeutsche Zeitung, Spanish El Pais, French Le Monde, Canadian Broadcasting Corp. and the British and US editions of The Guardian also sheds some light on the suspicious financial dealings of the Chinese political elite (Hollande zapowiada walkę, 2013; Raje podatkowe maja, 2013; Londyn idzie na wojnę, 2013).

The European Union and EU member states struggling with excessive sovereign debt find the issue of efficient tax collection one of the most important elements of effective economic governance and of efficient recovery from the crisis. The first ICIJ publication was only a prelude to a great public debate on this topic. Not much later, in 2014, another leak occurred, commonly known as "Lux Leaks." At the end of 2014, European society and institutions were shaken by new reports about the multiannual controversial tax practices of Luxembourg, carried out when Jean Claude Juncker, the incumbent President of the European Commission, was the Prime Minister of Luxembourg. PricewaterhouseCoopers has helped multinational companies obtain at least 548 tax rulings in Luxembourg from 2002 to 2010. These legal, secret deals feature complex financial structures designed to create drastic tax reductions. The rulings provide written assurance that companies' tax-saving plans will be viewed favorably by the Luxembourg authorities. A separate set of documents reported on by ICIJ expanded the list of companies seeking tax rulings from Luxembourg to include American entertainment icon The Walt Disney Co., the politically controversial Koch industries and 33 other firms. The new files revealed that alongside PwC tax rulings were others brokered by Ernst \& Young, Deloitte and KPMG, among other accounting firms. Companies have channeled hundreds of billions of dollars through Luxembourg and saved billions of dollars

\footnotetext{
${ }^{3}$ Unfortunately, there is no information about Poland on the interactive map Offshore Leaks Database.

${ }^{4}$ A highly interesting report on the specific functioning of OFCs and its outcomes has been drawn up for the US Congress by the Congressional Research Service (CRS) which is in charge of political and legal analyses. Cf.: Gravelle, 2013.
} 
in taxes. Some firms have enjoyed effective tax rates of less than $1 \%$ on the profits they have shuffled into Luxembourg. Pepsi, IKEA, AIG, Coach, Deutsche Bank, Abbott Laboratories and nearly 340 other companies have secured secret deals from Luxembourg that allowed many of them to slash their global tax bills (Wayne, Carr, Guevara, Cabra, Hudson, 2014).

Faced with such alarming reports, President Juncker put forward a proposal to introduce the obligation to exchange information on tax decisions. In his opinion, the differences in tax systems of EU member states allow international companies to take advantage of them in ways that are not always honest and ethical. Combating tax evasion and tax avoidance became one of the political priorities of the European Commission. In 2014, the EC agreed that the main objective is to ensure that companies are taxed in the locations where they generate profits, and that they cannot avoid paying fair taxes due to aggressive tax planning. Commissioners were in agreement that the transparency of taxes paid by legal persons should be sought first and foremost. ${ }^{5}$ Therefore, an important communiqué from June 2012 adopted a comprehensive attitude and discussed different ways to improve the existing measures. Potential new initiatives were also presented on the national, EU and international levels in order to eliminate tax abuse and tax avoidance in Europe. These steps resulted in An Action Plan to strengthen the fight against tax fraud and tax evasion, an EC document from December 2012 (An Action Plan to, 2012). Since February 2015, a parliamentary Special Committee TAXE has operated with increasing efficiency dealing with the interpretation of tax law in EU member countries and other practices resulting in preferential taxation. Additionally, in March 2015, the European Commission presented a new package of measures to increase tax transparency, including the main element of automatic information exchange between EU member states on their respective interpretations of tax law. The EC also announced its readiness to restart work on the common corporate tax base. The EC presented a draft directive on the Common Consolidated Corporate Tax Base (CCCTB) by virtue of which, instead of adapting to different requirements valid in different EU countries where the companies operate, they would apply a set of uniform principles to calculate their taxable income. The level of tax rates for natural persons, however, would continue to be set by member states. In 2011, EU member states were not interested in implementing this solution, but after four years the European Commission recorded their increased interest in such a measure.

The debate on harmful tax competition additionally heated up in the wake of yet another tax scandal known as "Swiss Leaks" (HSBC files). It revealed more examples of tax dodging by the most affluent citizens and corporations in the world through the Swiss branch of HSBC, the second biggest bank in the world. For years, HSBC assisted its well-to-do customers from all over the world, including Poland, in hiding their profits from tax authorities. Hervé Falciani, a controversial IT expert and Italian and French citizen, moved from HSBC Monaco to HSBC Private Bank in Geneva in 2006 and testified that he had a team of workers whose task was to assist clients in concealing their identities and secret transactions. They provided advice, for instance, on how to establish companies in tax havens, how to transfer money to Switzerland in a way allowing them

${ }^{5}$ Grey zone in all EU member states is estimated at the level of nearly 1/5 of GDP, that is nearly EUR 2 billion. For more cf.: Jak funkcjonuje zarzqdzanie, 2014; Unikanie podatków, 2015. 
to conceal it from tax authorities and how to withdraw money from bank accounts in a safe and secret manner. The nearly 60,000 HSBC files contained information about the accounts of 106,000 clients from 203 countries that the Swiss branch of the bank ran from 2005-2007. The total assets held in these disclosed accounts amounted to nearly USD 120 billion. Swiss Leaks was a collaborative investigation that exposed how the Swiss branch of one of the world's biggest banks profited from doing business with tax dodgers and criminals around the world. The documents, obtained by the International Consortium of Investigative Journalists via the French newspaper Le Monde, show the bank's dealings with clients engaged in a spectrum of illegal behavior, especially in hiding hundreds of millions of dollars from tax authorities. Secret documents reveal that global banking giant HSBC profited from doing business with arms dealers who channeled mortar bombs to child soldiers in Africa, bag men for Third World dictators, traffickers in blood diamonds and other international outlaws. Clients who held HSBC bank accounts in Switzerland include former and current politicians from Britain, Russia, Ukraine, Georgia, Kenya, Romania, India, Liechtenstein, Mexico, Lebanon, Tunisia, the Democratic Republic of the Congo, Zimbabwe, Rwanda, Paraguay, Djibouti, Senegal, Philippines and Algeria. They also show private records of famous soccer and tennis players, cyclists, rock stars, Hollywood actors, royalty, politicians, corporate executives and old-wealth families. The bank repeatedly reassured clients that it would not disclose details of accounts to national authorities, even if evidence suggested that the accounts were undeclared to tax authorities in the client's home country. Bank employees also discussed with clients a range of measures that would ultimately allow clients to avoid paying taxes in their home countries (Ryle, Fitzgibbon, Cabra, Carvajal, Guevara, Hamilton, Stites, 2015).

In June 2015, the United Nations Conference on Trade and Development (UNCTAD) reported that companies all over the world avoid paying a minimum USD 200 billion in taxes owing to offshore operations aimed to optimize taxes. UNTAD estimated that USD 450 billion of income generated in developing countries is shuffled offshore. As a consequence, the governments of these countries lose from USD 70-120 million in taxes. According to the estimates by the IMF, developed countries lose a minimum $0.6 \%$ of GDP (amounting to at least USD 100 billion of taxes paid annually) while developing countries lose nearly $2 \%$ of GDP. These estimates made the European Commission start a public debate in the forum of European institutions. In the Commission's opinion, tax fraud and dodging taxes curb the potential of EU member states to increase profits and implement fair and rational economic policies. The biggest business entities and the richest citizens continue to profit from tax optimization procedures, failing to adequately contribute to their national budgets, thereby arousing exasperation and utterly justified social anger. Fair-playing taxpayers should not bear the additional burden of increased taxes in order to balance out losses incurred on account of tax fraudsters and entities that legally avoid taxation in their home countries. As the influential The Economist rightly wrote "...corruption makes the world poorer and less equal. When politicians steal, they reduce the amount of public cash left over for roads or schools. When they give sweetheart contracts to their chums, they defraud taxpayers and deter honest firms from investing in their country. All this hobbles growth. Cleaning up tax havens will not end graft. The prime responsibility for this lies with national governments, many of 
which should do more to make their finances transparent and their safeguards against cronyism stringent. But it would help if kleptocrats were less able to hide their stashes. Hence coordinated global efforts are required to crack down on corporate anonymity and to stop the middlemen who make it so easy for crooks to launder their loot" (Leak of the century, 2016).

The European Union of 2016 should look very attentively at combating tax fraud and tax evasion as well as stir up public debate about "the civic duty" to pay taxes (Communication from the Commission, 2012; Interpretacja podatkowa, 2015).

\section{The Panama Papers and the leak's consequences for the global economy}

Despite all their merits, all the above mentioned leaks were just a fraction of what the ICIJ has managed to document within the Panama Papers scandal. The ICIJ in 2016 published a searchable database that strips away the secrecy of thousands of offshore entities created in many jurisdictions, from Nevada to Hong Kong and the British Virgin Islands. The data, part of the Panama Papers investigation, is the largest ever release of information about offshore companies and the people behind them. This includes, where available, the names of the real owners of those opaque structures. The database also displays information about more than 100,000 additional offshore entities ICIJ had already disclosed in its 2013 Offshore Leaks investigation.

The cache of 11.5 million records shows how a global industry of law firms and big banks sells financial secrecy to politicians, fraudsters and drug traffickers, as well as billionaires, celebrities and sports stars. The 2.6 terabytes of data are thought to contain information about 214,500 companies in 21 offshore jurisdictions and name over 14,000 middlemen (such as banks and law firms) with whom the law firm has allegedly worked. The leak provides details of the hidden financial dealings of 128 more politicians and public officials around the world. The data includes emails, financial spreadsheets, passports and corporate records revealing the secret owners of bank accounts and companies, from Nevada to Singapore to the British Virgin Islands (Obermayer, Ryle, Guevara, Hudson, Bernstein, Fitzgibbon, Cabra, Hamilton, Obermaier, Chittum, Diaz-Struck, Carvajal, Schilis-Gallego, Rey, Reuter, Galizia, Boland-Rudder, Fiandor, Torres, 2016).

The files expose offshore companies controlled by the prime minister of Iceland, the king of Saudi Arabia, the president of Ukraine, the children of the president of Azerbaijan and the prime minister of Pakistan. In the scandal, names were also mentioned of friends or relatives of the presidents of Russia, China, Syria, Argentina and the Republic of South Africa, the king of Morocco, Prime Minister of Great Britain, former Italian Prime Minister, Lionel Messi, Michel Platini, Pedro Almodovar and Emmy Watson. They also include at least 33 people and companies blacklisted by the U.S. government because of evidence that they'd been involved in wrongdoing, such as doing business with Mexican drug lords, terrorist organizations like Hezbollah or rogue nations like North Korea and Iran. These are among the findings of a yearlong investigation by the International Consortium of Investigative Journalists, German newspaper Süddeutsche Zeitung and more than 100 other news organizations (Ibid.; Wojtasik, 2016; Bielecki, 2016; Żelazny, 2016). 
Most of the services the offshore industry provides are legal if used by the law abiding. But the documents show that banks, law firms and other offshore players have often failed to follow legal requirements that they make sure their clients are not involved in criminal enterprises, tax dodging or political corruption. In some instances, the files show, offshore middlemen have protected themselves and their clients by concealing suspect transactions or manipulating official records. The documents make it clear that the major banks are the big drivers behind the creation of hard-to-trace companies in the British Virgin Islands, Panama and other offshore havens. The files list nearly 15,600 paper companies that banks set up for clients who want keep their finances under wraps, including thousands created by international giants UBS and HSBC. The leaked records - which were reviewed by a team of more than 370 journalists from 76 countries - come from a little-known but powerful law firm based in Panama, Mossack Fonseca, that has branches in Hong Kong, Miami, Zurich and more than 35 other places around the globe. The firm is one of the world's top creators of shell companies, corporate structures that can be used to hide ownership of assets. Mossack Fonseca, a Panama-based law firm, has for almost 40 years, specialized in registering companies on behalf of clients in jurisdictions that make little information available about who is really behind a company name. Among them are the more commonlyknown secrecy jurisdictions like Panama, Jersey, the Bahamas and the Seychelles. But the law firm also helped clients incorporate companies in places not commonly associated with "offshore" finance, like the United Kingdom and the U.S. states Delaware, Wyoming and Nevada.

An ICIJ analysis of the leaked files found that more than 500 banks, their subsidiaries and branches have worked with Mossack Fonseca since the 1970s to help clients manage offshore companies. UBS set up more than 1,100 offshore companies through Mossack Fonseca. HSBC and its affiliates created more than 2,300 (Leak of the century, 2016; The Economist explains, 2016; Many men, 2016; Inside The Panama Papers).

Figure 2. The cash cache

Mossack Fonseca data leak, April 2016

Breakdown of the 11.5 millin documents

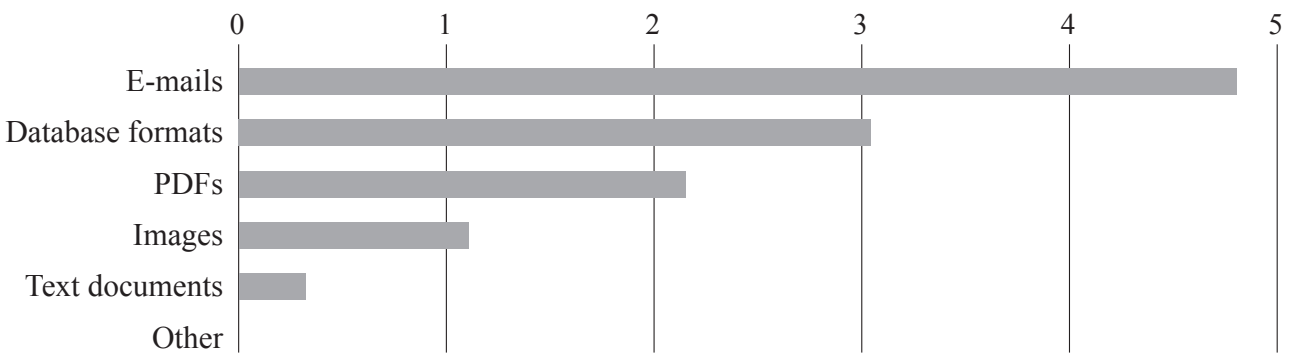

12 Current or former country leaders

128 Other politicians and public officials

Where the companies are registered, '000
29 Billionaires (Forbes list)

202 Countries/territories connected to the data

Source: "The Economist”, April 4, 2016. 


\section{Conclusions}

The transfer of income to countries with friendly tax systems, and taking advantage of complicated relations between subsidiaries in order to avoid taxation in the home country, is frequently compliant with the law. Therefore, this law should be amended to put an end to unfair and harmful tax competition once and for all (Krukowska, 2015). Non-governmental organizations, the media and universities have the task of publicizing, explaining and emphasizing this issue in society. The task of politicians is to solve the problem, which can be difficult, given their direct interest. In democratic states, dishonest and unethical authorities can be replaced by elections. and elections can be brought forward by means of mass protests. What is needed, to this end, is a new international agreement ensuring complete transparency and coordination of operations. Such an agreement may be instigated by the letter to the authorities and international institutions, written in May 2016 by a group of renowned economists, including the author of the best selling Capital in the Twenty-First Century, Thomas Piketty, Professor of Columbia University and adviser to UN Secretary General Ban Ki-moon, Jeffrey Sachs, and Professor of Princeton University and Nobel Winner, Angus Deaton. They called upon global leaders to make the global tax system more transparent. A total of over 350 economists from thirty states, ranging from Finland to Cameroon, signed this letter, warning that tax havens are a serious distortion of the global economy and have no economic justification whatsoever. The economists call upon governments, in particular the governments of the US and Great Britain, which, as Jeffrey Sachs rightly observes, have allowed the emergence of numerous tax havens, to make new global regulations pertaining to tax optimization. A new set of regulations should oblige companies to report business activities subject to taxation in every country where they operate. The signatories of the letter also demand that all states and territories release details of the actual ownership of companies and trusts (350 znanych ekonomistów, 2016). ${ }^{6}$ Some tangible outcomes of the reports by investigative journalists from the ICIJ and other influential circles could be noted as

${ }^{6}$ The work by Thomas Piketty, "Capital in the Twenty-First Century," is accompanied by another important academic publication by Jeremy Rifkin - "Zero Marginal Cost Society." These two comprehensive studies present an interesting and pessimistic picture of the world. Contrary to various concepts of optimistic supporters of neoliberal global capitalism, claiming that economic growth in the conditions of a free market economy will provide everybody with an opportunity to improve their economic situation, the reality shows the opposite trend. Capital, by its nature, tends to multiply itself, and not to multiply the income of the state. Contrary to the long-promoted model of an "information society and knowledge-based economy," which stresses the importance of intellectual capital in the modern postindustrial economy, the position of "classic" capital, measured by assets accumulated in real estate, means of production and financial assets, is still dominant. Piketty shows that in the $21^{\text {st }}$ century, the role of inherited capital in generating income has risen to an unprecedented level in history. The slower the development of economy, the greater the importance of the capital, and the smaller the personal merits of capital holders. Inherited capital multiplies itself, not always in a manner consistent with the law or ethics, which, tax havens evidence best. Ironically, such disparities are caused by the economic stagnation observed in Europe since 2008. The French economist argues that the slower an economy grows, the bigger the importance of capital rent. In theory, more egalitarian European societies, if measured by the range of income from work, are becoming increasingly stratified in terms of accumulated capital resources. The result is a sharp increase in social inequalities, disappointment, frustration and the social unrest associated with it! 
early as several weeks after the partial release of Mossack Fonseca leaks in Great Britain, France, the Netherlands, Norway, Canada, Japan, Kenya, Nigeria, Mexico, Indonesia, Vietnam and Panama. ${ }^{7}$

Following the gradually disclosed Panama Papers leaks and former reports by the ICIJ, the mechanism of "tax optimization" should be subjected to much more robust supervision, monitoring and transparency (Boland-Rudder, 2016). At the time of the aftermath of the global 2008+ crisis, states should be seeking all possible, obviously, legal solutions to increase budget income. The billions of dollars or euros obtained as a result of tighter taxation systems could be redistributed reasonably, thereby smoothing out growing income inequalities. There emerges the question of how to win social approval and implement efficient reforms, consisting in extending the working week, increasing the retirement age, higher taxes, and reduced social expenditure, when practically every week the average EU citizen learns about successive billions of euros in taxes which are due but unpaid. How can we prevent the social protests that are becoming increasingly radical, as evidenced in France and Belgium in May 2016? The average citizen cannot and should not bear the growing social expenditure of the crisis when big business and the richest citizens deliberately, even if legally, avoid paying taxes. One of the worst outcomes of financial globalization that should be decidedly combated is that globalization generates private income at public expense ("private gains-public losses"). In order not to discuss tax avoidance exclusively in terms of ethics, concrete legislation is indispensable both at the level of specific states, the US and Great Britain first and foremost, and within the framework of a new global agreement. UNCTAD appears to be the best platform for such a solution, followed by the OECD (although a drawback of it is the absence of Russia) and the WTO. In order to arrive at a solution in the foreseeable future, however, a broad public and political debate is necessary (preferably at the level of the G-7) as well as extensive publicity given to the detrimental outcomes of tax evasion. Polish public opinion also deserves such an extensive and thorough debate on this topic, including discussion in the parliament. Governments, community and international institutions are in charge of regulating and curbing tax optimization. NGOs, universities and the media are facing the task of initiating a public debate on these issues that should now be discussed also in Poland the way other countries have discussed them. This needs to be followed by adequate legal changes, that the Polish parliament has consistently been implementing for several months, which deserves praise.

\section{Bibliography}

350 znanych ekonomistów: raje podatkowe nie majq uzasadnienia (2016), http://wyborcza.biz/biznes/1,148065,20046292,350-znanych-ekonomistow-raje-podatkowe-nie-maja-uzasadnienia. html\#ixzz49J81qGov, 09.05.2016.

62 people own the same as half the world, reveals Oxfam Davos report (2016), "The Economist", 18.01.2016.

7 The ICIJ is not publishing the totality of the leak, and it is not disclosing raw documents or personal information. The database contains a great deal of information about company owners, proxies and intermediaries in secrecy jurisdictions, but it doesn't disclose bank accounts, email exchanges and financial transactions contained in the documents. 
An Action Plan to strengthen the fight against tax fraud and tax evasion, Communication from the Commission to the European Parliament and the Council, Brussels, December 6, 2012, COM(2012) 722 final, $\{\mathrm{SWD}(2012) 403$ final $\}\{\mathrm{SWD}(2012) 404$ final $\}$.

An Economy for the 1\%. How privilege and power in the economy drive extreme inequality and how this can be stopped (2016), 210 Oxfam Briefing Paper, 18.01.2016.

Bielecki J. (2016), Panama skusiła wszystkich, http://www.rp.pl/Panama-Papers/304049857-Panamaskusila-wszystkich.html, 04.04.2016.

Boland-Rudder H. (2016), US States Under Pressure As World Pushes For Financial Transparency, https://panamapapers.icij.org/20160513-us-states-london-summit.html, 13.05.2016.

Communication from the Commission to the European Parliament and the council on concrete ways to reinforce the fight against tax fraud and tax evasion including in relation to third countries European Commission, Brussels, 27.6.2012, COM(2012) 351 final.

Credit Suisse, Research Institute Thought leadership from Credit Suisse Research and the world's foremost experts, Global Wealth Report 2015, October 2015.

Fusion, Inside The Panama Papers: Dirty Little Secrets, https://www.youtube.com/ watch? $=$ TvPBM8zAc1o.

Gravelle J. G. (2013), Tax Havens: International Tax Avoidance and Evasion, Senior Specialist in Economic Policy, Congressional Research Service 7-5700, R40623, http://www.crs.gov, 23.01.2013.

Grzywacz J. (2011), Pranie pieniędzy. Metody/Raje podatkowe/Zwalczanie, Warszawa.

Henry J. S. (2012), Senior Advisor/Global Board Member, Tax Justice Network, July 2012, http://www. taxjustice.net/cms/upload/pdf/Price_of_Offshore_Revisited_120722.pdf.

Hollande zapowiada walke z rajami podatkowymi (2013), "Rzeczpospolita", http//www.ekonomia. rp.pl, 10.04.2013.

http//www. rajepodatkowe.com.pl.

http//www.irs.gov.

http//www.uglandhouse.ky.

$\mathrm{http} / / / \mathrm{www} \cdot$ financialsecrecyindex.com/.

http://www.oxfam.org.uk/media-centre/press-releases/2016/01/62-people-own-same-as-half-worldsays-oxfam-inequality-report-davos-world-economic-forum (62 people own same as half world - Oxfam 18th Jan, 2016).

http://www.rp.p1/Panama-Papers/160409670-Panama-informuje-o-sledztwie-w-sprawie-Panama-Papers.html, 05.04.2016.

Interpretacja podatkowa, raj podatkowy... - wszystko, co warto wiedzieć o podatkach, http://www. europarl.europa.eu/news/pl/news-room, 01.06.2015.

Jak funkcjonuje zarzqdzanie gospodarcze w UE? (2014), Komisja Europejska, Bruksela, 28 maja 2014, http://europa.eu/rapid/press-release_MEMO-13-979_pl.htm.

Krukowska M. (2015), 10 największych rajów podatkowych na świecie, http://csr.forbes.pl/najwiekszeraje-podatkowe-na-swiecie,artykuly,196503,1,1.html, 29.06.2015.

Kuciak I. (2012), Raje podatkowe w zmniejszaniu obciażeń podatkowych, Łódź.

Langer D. (2007), Przewodnik po rajach podatkowych.

Leak of the century, The lesson of the Panama papers (2016), "The Economist", 09.04.2016.

Lipowski T. (2002), Raje podatkowe - charakterystyka i sposoby wykorzystywania, Gdańsk.

Londyn idzie na wojnę z oszustami podatkowymi (2013), "Rzeczpospolita", http//www.ekonomia.rp.pl, 10.05.2013.

Many men, many plans, The furore from the Panama papers will only grow bigger (2016), "The Economist", 04.04.2016. 
Mazur Ł. (ed.) (2012), Optymalizacja podatkowa, Warszawa.

Obermayer B., Ryle G., Guevara M. W., Hudson M., Bernstein J., Fitzgibbon W., Cabra M., Hamilton M. H., Obermaier F., Chittum R., Diaz-Struck E., Carvajal R., Schilis-Gallego C., Rey M. G., Reuter D., Galizia M. C., Boland-Rudder H., Fiandor M., Torres M. (2016), Giant Leak of Offshore Financial Records Exposes Global Array of Crime and Corruption, https://panamapapers.icij. org/20160403-panama-papers-global-overview.html.

OECD (2010), Offshore Voluntary Disclosure, comparative analysis, guidance and policy advice, Paris.

Oxfam says wealth of richest 1\% equal to other 99\% (2016), http://www.bbc.com/news/business-35339475, 18.01.2016.

Raje podatkowe maja być bardziej transparentne (2013), "Rzeczpospolita”, http//www.ekonomia.rp.pl, 02.05.2013.

Ryle G., Fitzgibbon W., Cabra M., Carvajal R., Guevara M. W., Hamilton M. H., Stites T. (2015), SWISS LEAKS: MURKY CASH SHELTERED BY BANK SECRECY Banking Giant HSBC Sheltered Murky Cash Linked to Dictators and Arms Dealers, https://www.icij.org/project/swiss-leaks.

Special Report: offshore finance (2013), "The Economist", Storm Survivors, 16.02.2013.

The Economist explains, What are the Panama papers and why do they matter? (2016), "The Economist", 04.04.2016.

The Price of Offshore Revisited: Press Release - $19^{\text {th }}$ July 2012 (2012), http://www.taxjustice.net.

Unikanie podatków. Bruksela chce walczyć z optymalizacja podatkowa firm (2015), http://www.money.pl/gospodarka/unia-europejska/wiadomosci/artykul/unikanie-podatkow-bruksela-chcewalczyc-z,63,0,1716287.html.

Wayne L., Carr K., Guevara M. W., Cabra M., Hudson M. (2015), Deals in Luxembourg. Leaked Documents Expose Global Companies'Secret Tax, https://www.icij.org/project/luxembourg-leaks.

We've Already Solved Oxfam's Little Inequality Problem (2016), http://www.forbes.com/sites/timworstall/2016/01/18/weve-already-solved-oxfams-little-inequality-problem/\#7de29cf26122.

What does offshore mean? The popular financial term explained, www.taxhavensguide.com/tax-haven. php.

Winter L. (2010), Raje podatkowe. Raport specjalny, Warszawa.

Wojtasik P. (2016), Panama papers: ucieczka do raju podatkowego to spore oszczędności, http://www. rp.pl/Panama-Papers/160409670-Panama-informuje-o-sledztwie-w-sprawie-Panama-Papers. html, 05.04.2016.

Żelazny P. (2016), Złoczyńcy, których od dawna dobrze znamy, http://www.rp.pl/PanamaPapers/304049853-Zloczyncy-ktorych-od-dawna-dobrze-znamy.html, 04.04.2016.

\section{Problem narastających nierówności dochodowych w świecie a zjawisko szkodliwej konkurencji podatkowej. ICIJ na tropie największych afer finansowych XXI wieku}

\section{Streszczenie}

W maju 2016 roku ponad 350 ekonomistów z 30 krajów świata podpisało się pod listem do światowych liderów politycznych z grupą G-7 na czele, ostrzegając, że działanie rajów podatkowych jest nie tylko niesprawiedliwe społecznie, ale też nie ma współcześnie jakiegokolwiek uzasadnienia ekonomicznego. Autor bestsellerowej pracy naukowej Kapitat w XXI wieku Thomas Piketty, profesor Columbia University i doradca sekretarza generalnego ONZ Jeffrey Sachs, profesor Princeton University i laureat Nagrody Nobla Angus Denton oraz wielu innych cenionych autorytetów naukowych wezwali do wprowadzenia większej przejrzystości w globalnym systemie podatkowym i wprowadzenia regula- 
cji ograniczających funkcjonowanie tzw. OFC. Także organizacja pozarządowa Oxfam International, która koordynowała stworzenie listu, wezwała światowych liderów do ustalenia wspólnego stanowiska w sprawie ukrócenia tajemnicy związanej z funkcjonowaniem spółek w rajach podatkowych, ujawniając szkody, jakie one przynoszą. Tzw. optymalizacja podatkowa w opinii cytowanych w artykule analityków Oxfam, Credit Suisse i UNCTAD przyczynia się do pogłębiania globalnych nierówności dochodowych, traktowanych jako największy problem globalny XXI wieku. Autor, powołując się na ww. analizy naukowe oraz wyniki śledztwa dziennikarskiego Międzynarodowego Zrzeszenia Dziennikarzy Śledczych (ICIJ), stara się zdiagnozować i przybliżyć te wzajemne zależności, ukazać wielorakie szkody, jakie proceder ten przynosi gospodarkom i społeczeństwom, prezentując własne oceny i prognozy na przyszłość.

Słowa kluczowe: szkodliwa konkurencja podatkowa, ekonomia globalna, zróżnicowanie dochodowe, raje podatkowe 
